\title{
GAMBARAN TINGKAT KEJADIAN ANEMIA DAN PERKEMBANGAN BALITA USIA 6 - 60 BULAN
}

\section{An OVERVIEW of the DEVELOPMENT of TODDLERS ages 6 to 60 MONTHS and the INCIDENCE RATE of ANEMIA on the Group}

\author{
Endah Puji Astuti ${ }^{1 *}$, Ratna Prahesti ${ }^{2}$, Ana Dwi Andriyani ${ }^{3}$ \\ ${ }^{123}$ Stikes A. Yani Yogyakarta, Jln. Ringroad Barat Gamping Sleman Yogyakarta Kode Pos 552894 Indonesia
}

\section{Informasi Artikel: \\ Diterima: Mei 2016}

Disetujui: Oktober 2016

\section{Kata kunci:}

Balita, perkembangan

balita, Anemia, anemia

balita

\begin{abstract}
ABSTRAK
Di Indonesia lebih dari separuh anak bawah lima tahun (balita) mengalami masalah gizi kurang atau malnutrisi. Malnutrisi dapat menyebabkan gangguan pertumbuhan, penurunan fungsi kognitif, psikomotor dan daya tahan tubuh anak, karena pada umumnya anak yang malnutrisi selain kekurangan energi dan protein juga mengalami kekurangan berbagai mikronutrien. Tujuan penelitaian untuk mengetahui gambaran perkembangan balita dan tingkat kejadian anemia pada kelompok tersebut. Jenis penelitian deskriptif dengan pendekatan cross sectional. Populasi penelitian adalah semua balita usia 6 bulan -5 tahun sebanyak 603 balita. Sampel diambil dengan purposive sampling sebanyak 158 balita. Pengambilan data primer menggunakan penilaian Denver Development Screening Test (DDST) dan Digital Haemoglobin Test. Analisis yang digunakan adalah kendall's tau. Hasil penelitian menunjukkan bahwa sebanyak 49,4\% balita mengalami anemia ringan, dan $69,6 \%$ berada dalam perkembangan normal. Mayoritas balita yang mengalami anemia tetap memiliki perkembangan normal.
\end{abstract}

\begin{abstract}
In Indonesia, there are more than half of under-five children suffer from malnutrition resulting in growth retardation, the decrease of cognitive function, psychomotor and the immune system of children. These problems occur because children suffering from malnutrition will experience lack of energy and protein as well as the shortage of some important micronutrients. The purpose of the research to know the description of the development of toddlers and the incidence rate of anemia on the group. This was an analyticalcorrelation research which involved a cross sectional approach. The population of the research included 603 toddlers aged 6 months-5 years old with research samples by 158 toddlers taken by purposive sampling. The primary data were collected using Denver Development Screening Test (DDST) dan Digital Haemoglobin Test. The analysis used Kendall's tau. The result showed that 49,4\% of toddlers suffered from mild anemia, and 69,6\% of them had normal development. The majority of toddlers suffering from anemia also had normal development.
\end{abstract}




\section{PENDAHULUAN}

Pembangunan nasional bertujuan meningkatkan kualitas sumberdaya manusia secara berkesinambungan dan berkelanjutan. Kualitas sumberdaya manusia ditentukan oleh keberhasilan tumbuh kembang pada masa kanak-kanak (Depkes RI 2000). Investasi yang dimulai sejak dini (usia anak-anak) dianggap paling menguntungkan di dalam pembangunan SDM. Faktor utama yang mempengaruhi tumbuh kembang anak diantaranya adalah faktor gizi, kesehatan dan pengasuhan (caring) yang terkait satu sama lain. Anak kekurangan gizi memiliki IQ yang kurang, hal ini bukan hanya disebabkan oleh makanan saja, tetapi lebih disebabkan oleh kekurangan stimulus dari orang tua yang biasanya juga menderita kekurangan gizi.

Umur anak di bawah 5 tahun merupakan periode yang menentukan kualitas hidupnya di masa yang akan datang. Keterlambatan pertumbuhan dan perkembangan merupakan masalah yang sering dijumpai di masyarakat, tetapi terkadang kurang mendapatkan penanganan yang tepat. Banyak orangtua yang menunda penanganan keterlambatan perkembangan mengakibatkan prognosis yang kurang baik.

Clark (2008) mengungkapkan bahwa malnutrisi dalam wujud anemia defisensi besi memberikan dampak yang luas termasuk menurunkan kapasitas kerja, menurunkan regulasi panas, disfungi imunitas, gangguan saluran cerna, dan menurunkan kemampuan kognitif. Olney, et al (2007) mengungkapkan bahwa anak yang kurang gizi mengalami hambatan dalam perkembangan motorik, demikian pula dengan anak yang anemia defisiensi besi. Sejalan dengan pedapat Sutaryo (2003), tingginya prevalensi anemia, terutama anemia akibat kekurangan besi, dapat mempengaruhi pertumbuhan dan perkembangan, karena besi sangat diperlukan untuk pembelahan sel dan sintesis hemoglobin, juga beperan pada sintesis DNA, neurotransmiter dan sitokrom mitikodria. Jadi, kekurangan besi dapat menggangu sintesis DNA.

\section{METODE PENELITIAN}

Jenis penelitian deskriptifbdengan pendekatan cross sectional yaitu dalam waktu bersamaan balita diperiksa $\mathrm{Hb}$ dan perkembangannya menggunakan lembar DDST (Denver Development Screening Test). Populasi dalam penelitian adalah semua balita usia 6-60 bulan di salah satu desa di daerah Gamping Sleman Yogyakarta yang mengikuti posyandu.

Jumlah sampel 158 balita yang diambil dengan metode purposive sampling. Hasil pengukuran anemia dikategorikan menjadi normal/tidak anemia, anemia ringan, sedang, dan berat (WHO, 2002). Pengukuran tingkat perkembangan balita menggunakan instrument Denver Development Screening Test (DDST)

\section{HASIL DAN PEMBAHASAN}

Dibawah ini adalah karakteristik demografi balita yang menjadi sampel penelitian.

Tabel 1: Karakteristik Balita

\begin{tabular}{lcc}
\hline \multicolumn{1}{c}{ Karakteristik } & $\mathrm{N}$ & $\%$ \\
\hline Usia & & \\
6-24 bulan & 67 & 42,41 \\
25-48 bulan & 74 & 46,84 \\
49-60 bulan & 17 & 10,76 \\
\hline Jenis kelamin & & \\
Laki-laki & 76 & 48,1 \\
Perempuan & 82 & 51,9 \\
\hline Pendidikan anak usia dini & & \\
Ikut PAUD & 83 & 52,53 \\
Tidak ikut PAUD & 75 & 47,47 \\
\hline Pemberian ASI & & \\
ASI eksklusif & 112 & 70,89 \\
Tidak ASI eksklusif & 46 & 29,11 \\
\hline
\end{tabular}

(Sumber: Data Primer, 2015)

Tabel 1 menunjukkan bahwa mayoritas balita berumur $13-60$ bulan $(86,07 \%)$, berjenis kelamin perempuan $(51,9 \%)$, mengikuti PAUD $(52,53 \%)$ dan diberikan ASI eksklusif (70,89\%).

Perkembangan balita dideskripsikan dalam tabel sebagai berikut: 
Endah Puji Astuti ${ }^{l^{*}}$, Ratna Prahesti ${ }^{2}$, Ana Dwi Andriyani ${ }^{3}$

Gambaran Tingkat Kejadian Anemia ...

Tabel 2: Gambaran perkembangan Balita

\begin{tabular}{ccc}
\hline Perkembangan & N & \% \\
\hline Normal & 110 & 69,6 \\
Suspect & 48 & 30,4 \\
Total & $\mathbf{1 5 8}$ & $\mathbf{1 0 0}$
\end{tabular}

(Sumber: Data Primer, 2015)

Tabel 2 menunjukkan bahwa sebagian besar balita mengalami perkembangan normal, yaitu 110 responden $(69,6 \%)$.

Anemia pada balita dideskripsikan dalam tabel sebagai berikut:

Tabel 3 : Gambaran kejadian anemia Pada Balita

\begin{tabular}{lcc}
\hline \multicolumn{1}{c}{ Klasifikasi Anemia } & $\mathbf{N}$ & $\mathbf{\%}$ \\
\hline Tidak anemia/Normal & 62 & 39,2 \\
Anemia ringan & 78 & 49,4 \\
Anemia sedang & 14 & 8,9 \\
Anemia berat & 4 & 2,5 \\
Total & $\mathbf{1 5 8}$ & $\mathbf{1 0 0}$ \\
\hline
\end{tabular}

(Sumber: Data Primer, 2015)

Tabel 3 menunjukkan bahwa sebagian besar balita mengalami anemia ringan, yaitu 78 responden $(49,4 \%)$.

\section{Gambaran Perkembangan Balita}

Perkembangan (development) adalah bertambahnya kemampuan dalam struktur dan fungsi tubuh yang lebih kompleks dalam pola yang teratur dan dapat diprediksikan. Sebagai hasil dari proses pematangan menyangkut adanya proses diferensiasi dari sel -sel tubuh, jaringan tubuh, organ-organ, dan sistem organ yang berkembang sedemikaian rupa sehingga masing-masing dapat memenuhi fungsinya termasuk juga perkembangan emosi, intelektual, dan tingkah laku sebagai hasil interaksi dengan lingkungan.

Hasil penelitian perkembangan ini menunjukkan bahwa paling banyak balita mengalami perkembangan normal, yaitu $69,6 \%$ dan suspect $30,4 \%$. Faktor yang berperan terhadap terjadinya perkembangan balita yang normal maupun suspect adalah, contohnya, faktor lingkungan, yaitu tempat anak tersebut hidup yang berfungsi sebagai penyedia kebutuhan dasar anak (provider). Hubungan anak dengan lingkungan berpengaruh misalnya dalam proses perkembangan bahasa pada anak yang jarang diberi stimulasi, atau jarang diajak bicara atau mendengar orang lain berbicara akan lebih lambat mempunyai ketrampilan berbicara. Kondisi psikologis dari lingkungan juga berpengaruh. Seorang anak yang tidak dikehendaki oleh orangtuanya atau anak yang selalu merasa tertekan dapat mengalami hambatan dalam pertumbuhan dan perkembangannya. Pada pola asuh, interaksi ibuanak sangat memengaruhi tumbuh kembang anaknya. Perkembangan akan berbeda antara anak yang di asuh oleh ibu atau oleh pembantu ataupun nenek dari balita tersebut.

Menurut Departemen kesehatan (2005), beberapa faktor mempengaruhi perkembangan, yaitu ras/etnik atau bangsa, keluarga, umur, jenis kelamin, genetik, asupan gizi, adanya infeksi, kelainan imunologi, faktor psikologis, lingkungan, sosial ekonomi, pola asuh, dan stimuasi. Perkembangan fisik, khususnya kemampuan motorik kasar, akan meningkat dengan sempurna dalam permainan yang aktif, bebas dan tidak terstruktur. Dalam penelitian ini, sebagian besar balita terbiasa bermain diluar rumah dengan teman-temannya seperti bermain bola, lari-lari, loncat-loncat dan lain sebagainya.

\section{Gambaran tingkat kejadian Anemia pada Balita}

Sebagian besar mengalami anemia ringan, yaitu $49,4 \%$ dan hanya $2,5 \%$ yang mengalami anemia berat. Menurut Nursalam (2005), anemia defisiensi zat besi $(\mathrm{Fe})$ merupakan anemia yang terjadi karena kekurangan zat besi yang merupakan salah satu bahan baku pembuat haemoglobin. Anemia difisiensi zat besi disebabkan asupan nutrisi yang tidak seimbang seperti kekurangan zat besi, vitamin B 12, asam folat, itamin $\mathrm{C}$ dan protein sel darah merah (eritrosit) Sudarti (2010).

Balita yang tidak mengalami anemia (normal) adalah 39,2\%, dan yang diberikan ASI eksklusif sampai usia 6 bulan adalah sebanyak $70,89 \%$. Setelah usia 1 tahun, beberapa orangtua 
mengatakan bahwa anaknya mengalami susah makan, lebih suka makan snack dan minum susu formula dibandingkan memakan sayur, lauk dari hewani maupun buah-buahan. Banyak orangtua yang merasa tenang walaupun anaknya mengalami susah makan tapi mau minum susu formula setiap hari. Kebiasaan ini bisa menyebabkan anemia pada balita, yang sesuai pendapat Arisman (2004) bahwa anemia defisiensi zat besi pada balita biasanya terjadi pada anak yang terlalu banyak mengonsumsi susu sehingga enggan untuk menyantap makanan lain terutama sayuran hijau.

Rendahnya konsumsi zat besi akan berpengaruh terhadap status gizi anak balita dan dapat terjadi kekurangan zat besi, sehingga mengakibatkan kadar hemoglobin $(\mathrm{Hb})$ darah menurun dan menyebabkan anemia. Untuk mengatasi hal ini, selain diberikan suplementasi zat besi, anak harus pula diberi dan dibiasakan menyantap makanan yang mengandung zat besi antara lain umbi-umbian, sayuran, kacang, daging, ikan, unggas, dan lain-lain. Hal ini menunjukkan bahwa baik buruknya status gizi seseorang dapat dilihat salah satunya dari konsumsi makanannya. Kebanyakan anak balita mengalami susah makan, sehingga asupan makanannya berkurang, terutama zat besi, dan akhirnya pertumbuhan dan perkembangannya terhambat.

\section{KESIMPULAN}

Pada penelitian ini, sebagaian besar balita mengalami perkembangan normal dan anemia ringan. Akan tetapi, anemia pada balita dalam penelitian ini tidak mempunyai hubungan dengan perkembangannya.

\section{DAFTAR PUSTAKA}

Arisman. 2004. Gizi dalam kehidupan : buku ajar ilmu gizi. Buku kedokteran. EGC : Jakarta

Clark, SF. 2008. Iron Deficiency Anemia. Nutrition in Clinical Practice, 23(2): 128-141

Departemen Kesehatan RI dan JICA. 2000. Buku Kesehatan Ibu dan Anak. Jakarta.

DepKes RI. 2005. Manajemen laktasi buku panduan bagi bidan dan petugas kesehatan di puskesmas. http://www.depkes.go.id. Diakses 10 April 2015.

Irianto, K dan Waluyo, K. 2004. Gizi dan pola hidup sehat. Yrama Widya : Bandung.

Notoatmodjo, S. 2007. Metodologi Penelitian Kesehatan. Jakarta : Rineka Cipta

Nursalam, dkk. 2005. Asuhan keperawatan bayi dan anak ( untuk perawat dan bidan) Edisi 1. Jakarta : Salemba Medika.

Olney,DK., dkk. 2007. Young Zanzibar Children with Iron Deficiency, Iron Deficiency Anemia, Stunting, or Malaria HaveLower MotorActivity Scores and Spend Less Timein Locomotion. J. Nutr; 137:2756-62

Sutaryo. Aspek Klinis Anemia Defisiensi Besi. Dalam : Seminar Anemia Defisiensi Besi, Yogyakarta, April, 2003.

Sudarti. 2010. Asuhan kebidanan neonatus, bayi dan anak balita. Yogyakarta ; Nuha Medika.

Zulaikah S, Setyo P dan Listyani H. 2014. Anemia Terhadap Pertumbuhan Dan Perkembangan Anak Malnutrisi. Jurnal Kesehatan Masyarakat Volume 2, Nomer 9 hal 106-114. http://journal.unnes.ac.id/nju/index.php/kema $\mathrm{s}$ 